\title{
The role of manpower planning in the corporate planning process
}

\author{
Jay Owens* and Lila Nema \\ Graduate School of Business Administration, P.O. Box 31170, University of the Witwatersrand, Braamfontein, 2017 \\ Republic of South Africa
}

\begin{abstract}
The purpose of this article is to evaluate how wide-spread the use of, as well as how comprehensive manpower planning is in South African organizations. It also explores how well integrated manpower planning is in the strategic planning of organizations. A review of the planning and corporate planning literature is undertaken. A sample of 25 companies from the Financial Mail 'Top 100 Companies' was selected for analysis. Conclusions are drawn from the findings, and a list of recommendations has been drawn up which will enable companies to improve their manpower planning in a changing South Africa.
\end{abstract}

Die doelwit van hierdie artikel is om ondersoek in te stel na die omvattendheid asook die deeglikheid van mannekragbeplanning in Suid-Afrikaanse maatskappye. Dit is verder 'n ondersoek na hoe geïntegreerd hierdie mannekragbeplanning in die strategiese beplanning van hierdie maatskappye is en bied 'n literêre oorsig van die veld aan. Vyf-en-twintig maatskappye uit die Financial Mail 'Top 100 Companies' is ontleed. Met die gevolgtrekkings wat uit die ondersoek voortgespruit het, is 'n lys van aanbevelings opgestel van wat 'n maatskappy kan doen om mannekragbeplanning op te knap in 'n veranderende Suid-Afrika.

* To whom correspondence should be addressed

\section{Introduction}

South Africa faces the prospect of a severe shortage of skilled, professional and managerial manpower in the decades ahead. This shortage of high-level human resources has been investigated and documented by many researchers and resulted in an initial investigation and report by the National Manpower Commission in 1980. Because of historical circumstances, the source of high-level manpower has been the white population and during periods of low economic growth, the supply has roughly matched the demand. However, during periods of high economic growth there has been a shortage which could not be met from internal sources.

Traditionally, this shortage has been met by means of 'imports' from overseas countries, but it is doubtful whether this source will be available during the decades ahead. Firstly, the numbers required will be greater than the numbers that will be attracted to the country under the present conditions. Secondly, and more importantly, it is doubtful whether the continued 'import' of skills will be defendable within the context of the current social and political environment. The problem is further exacerbated by the so-called 'brain drain' of high-level manpower from South Africa. Recent figures released by the Central Statistical Services Office indicate a nett outflow of 5852 during the first 10 months of 1986 (Financial Mail, 1987).

Stable urbanized communities and constant improvements in the level of general education are giving rise to increased needs and aspirations amongst the black population. These needs can only be satisfied by greatly improved occupational opportunities. Moreover, the existing investment in providing training and occupational experience is so great that the black employee cannot be regarded as anything but a major stakeholder in the national economy. This means improved prospects for pay and job advancement, and the provision of additional training and developmental opportunities. The inescapable conclusion is that South
Africa must become self-sufficient in terms of its manpower needs.

Business survival depends upon the availability of adequate manpower. In the short term the onus is, without doubt, on the private sector to meet the challenge of providing the training and developmental requirements.

Management is most favourably placed to determine specific needs and shortcomings and to provide the resources which are required to meet these needs. This will only be achieved effectively through adequate and systematic planning and the efficient execution of these plans. An effective manpower plan, if it is to meet the organization's long-term needs, should determine not only the future complement of personnel required to operate the business, but also specify the knowledge, skills and competencies that will be required.

The purpose of this study is to evaluate how widespread the use of and how comprehensive manpower planning is in the South African context, and how well integrated manpower planning is in the strategic or corporate planning process in general.

In 1973, Management Journal (1974: 41), in association with the PE Consulting Group, conducted a survey amongst the Financial Mail 'Top 100' Companies with a view to determining the extent to which longrange planning was prevalent in these companies. Table 1 depicts the outcome of this exercise, showing the extent to which planning took place in key functional areas within the companies surveyed.

From the information presented in Table 1 it can be concluded that a decade ago, only slightly more than half $(53 \%)$ of the companies surveyed included an extensive personnel plan in their long-range plans.

Later, Abratt (1983) undertook a study on the interrelationship between Human Resource Management and Corporate Strategy. The study was aimed at testing the proposition - 'In the 1980's the personnel manager will become part of the top 
Teble 1 Activities included in the planning process

\begin{tabular}{|c|c|c|c|}
\hline \multirow[b]{2}{*}{ Key functional areas } & \multicolumn{3}{|c|}{$\begin{array}{c}\text { Extent of inclusion in the } \\
\text { planning process (\%) }\end{array}$} \\
\hline & $\begin{array}{l}\text { Large } \\
\text { extent }\end{array}$ & $\begin{array}{l}\text { Some } \\
\text { extent }\end{array}$ & $\begin{array}{c}\text { Little/no } \\
\text { extent }\end{array}$ \\
\hline Finance & 94 & 6 & - \\
\hline Marketing & 75 & 22 & 3 \\
\hline Production & 72 & 19 & 9 \\
\hline Management & 66 & 27 & 7 \\
\hline Personnel & 53 & 39 & 8 \\
\hline Diversification/Disinvestment & 50 & 34 & 16 \\
\hline Organization design and development & 48 & 41 & 11 \\
\hline Research and development & 27 & 44 & 29 \\
\hline
\end{tabular}

(Source: Mgmt. 1974: 41)

management team of companies because human resource management is a vital part of the corporate strategy of the firm'.

The study revealed that the personnel managers of $83 \%$ of the selected companies were members of the top management team and that they participated in corporate strategy formulation. Although the Abratt study revealed a high degree of involvement of the personnel manager in corporate affairs, it does not examine the manpower planning contribution in corporate strategy formulation.

\section{Theoretical perspectives}

\section{Planning defined}

The proliferation of published material on formal planning has probably brought the significance of this all-important intelligence function to the notice of many members of top management. The literature has however failed to provide these practitioners, and academics alike, with an all-embracing common frame of reference. There is no generally accepted definition of the terms used and the activities involved. Authors have each derived their own terminology, which they then proceed to define. Although many of these definitions do bear some resemblance to one another, it is difficult to say with any certainty that exactly the same activities are being described. However, many authors, among them Drucker (1974), Anthony (1965), Scott (1965), Argenti (1971) Steiner (1969), Rossotti (1970) and Andrews (1971) agree that the planning function is composed of two distinct planning activities. On the one hand there is the area termed 'strategic planning', while on the other there is the area termed 'tactical' or 'operational' planning.

Steiner (1969) has proposed a conceptual model of the planning process which adequately embodies these two facets of planning. The model is depicted diagrammatically in Figure 1 and shows the three premises upon which the direction of the planning function will depend. The major part of this process is strategic in nature, where Steiner (1969: 34) defines strategic planning as ' ...the process of determining the major objectives of an organisation and the policies and strategies that will govern the acquisition, use and disposition of resources to achieve these objectives'.

The strategic plan generated from input obtained from the three premises establishes the framework, usually long-term in nature, within which the operational medium-term and short-term planning is formulated.

Steiner's (1969: 35) medium-range operational planning has characteristics quite different from strategic

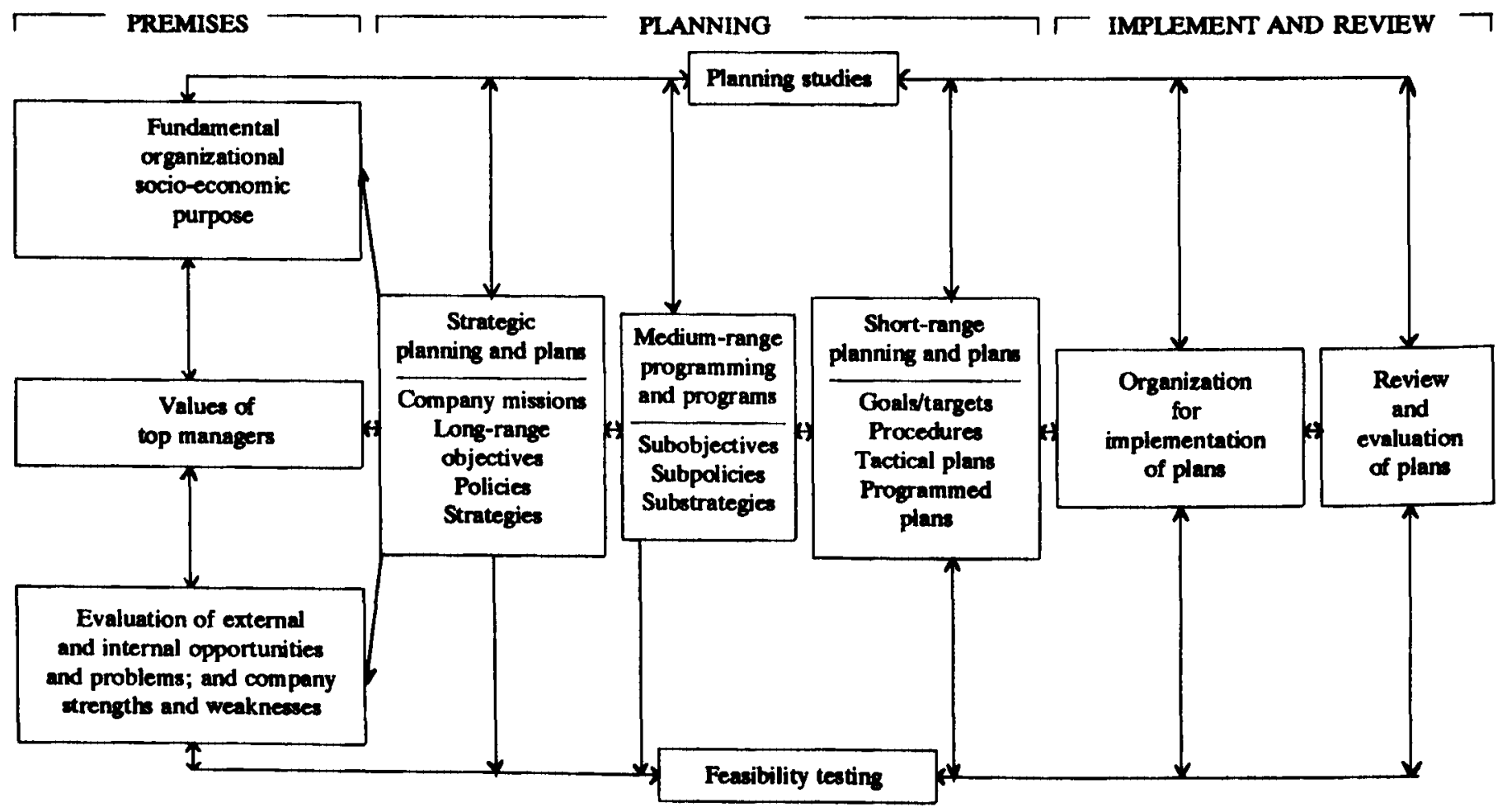

Figure 1 Structure and process of business planning (Source: Steiner, 1969: 33) 
planning and is defined as: 'The process in which detail, co-ordinated and comprehensive plans are made for selected functions of a business to deploy resources to reach objectives by following policies and strategies laid down in the strategic planning process'.

Steiner's short-term operational planning in turn refers to the numerous budgets and very detailed plans made for the same selected functions as in the mediumrange plans. These short-term plans are those which are implemented and executed. Steiner continues that it is the short-term operational plans which are used for control purposes.

Importantly, Anthony (1965) points out that strategic planning does not correspond to what a number of authors refer to as long-term planning. Whereas strategic planning provides the broad framework, namely, corporate objectives and strategy, within which alternative courses of action are examined, long-range planning refers to part of the operational plans flowing from strategic decisions. Both form part of the planning function, but they are not one and the same activity.

In order to establish an adequate planning framework to evaluate the manpower planning input, it was also important to determine precisely what planning was not. Both Drucker (1974: 123) and Steiner (1969) address this issue and conclude:

1. 'Planning is not forecasting ... a prediction, projection or estimate of future events...' (Steiner, 1969: 17), because these will always be inaccurate. Rather, in planning, the effort is to find the most probable future, derived with the aid of planning.

2. 'Planning is not making future decisions,... (rather it) is making current decisions in the light of their futurity' (Steiner, 1969: 18). This emphasizes one of the the fundamental premises of the planning function, namely, that planning is seeing what may be done today in the light of expectations regarding tomorrow.

3. 'Planning is not an attempt to eliminate risk' (Steiner, 1969: 18). Rather, the nature of the risk being faced by the organization must be understood through planning.

4. 'Planning is not a blueprint for the future' (Steiner, 1969: 18). Change and uncertainty in today's business environment make any blueprint useless. Rather, flexibility should be an innate feature of the planning process allowing plans to be changed if basic premises alter significantly.

5. 'Planning is not an aggregation of functional plans' (Steiner, 1969: 18). Rather, planning is a systematic approach to maneuvering an organization in such a manner as to reap synergistic effects in achieving aims and objectives.

\section{The corporate planning process}

Hussey \& Langham (1979) view the corporate planning process as an integrated system leading to the preparation of the various functional plans (for example, the marketing plan, manpower plan etc.). Their approach can be divided into three main phases: the review of strategy, plan preparation, and plan implementation.

The purpose of the review of strategy is to enable the organization to clarify its aims and intentions and set planning guidelines before committing the entire organization to the time-consuming task of working out detailed plans. This step is considered more important in a complex multidivision organization than in a simple type of operation. This step can prevent the frustrating task of having to rewrite the detailed plans at subsidiary level after they have been rejected by a higher authorizing body. The first phase, therefore, incorporates a participative review of strategies against the changing pattern of opportunities, external change, and shifts in the organization's own strengths and weaknesses.

This joint exercise leads directly into the Second Phase through the publication of the planning guidelines, assumptions, objectives, strategies and capital available. Phase 2 also incorporates a new review of the external factors to determine whether the planning assumptions are still valid.

A second formal review should follow which allows corporate and divisional management to explore deviation from the previously agreed strategies; the impact of any change in the internal or external circumstances on the agreed path; and the final shape of the plans in figures, particularly the expected profits, cash flows, and manpower. At this point, some formal analysis is also made of the risks and sensitivity of the results to changes in key factors.

Phase 3 represents the monitoring and control phase. Planning is unfortunately not an exact science. There are many factors that can make a plan inappropriate and review and monitoring becomes essential. This is usually achieved by the budgeting procedures, regular reviews and the formal audit.

\section{Research methodology}

\section{Population and sample selection}

The Financial Mail conducts an annual survey of all the companies listed on the Johannesburg Stock Exchange, ranking them by total assets, market capitalization, equity funds, net profits and turnover. For the purposes of this investigation, it was decided to use a target set comprising those companies on the Financial Mail 'Top 100 Companies' (Financial Mail, 1984) list and located in the PWV Area. From the 75 companies who met these criteria, a random sample of 25 companies was selected for the final analysis. A sample size of $30 \%$ was considered adequate for an exploratory study.

Table 2 reflects the final sample and the economic sectors from which the companies were drawn.

\section{Rationale}

As the primary purpose of this study was to determine the extent of the role played by manpower planning in the corporate planning process, it would seem logical to include those companies where the likelihood of formal planning was the greatest. The South African economy is 
Tablo 2 Sample by economic sector

\begin{tabular}{lc}
\hline Sector & No. in sample \\
\hline Beverages and Hotel & 1 \\
Stores & 2 \\
Industrial Holding & 8 \\
Engineering & 2 \\
Building and Construction & 3 \\
Printing and Publishing & 1 \\
Chemicals and Oils & 2 \\
Finance & 1 \\
Furniture and Household & 1 \\
Paper and Packaging & 2 \\
Food & 1 \\
Pharmaceutical & 1 \\
& \\
\end{tabular}

becoming increasingly characterized by a growing domination by a handful of large and diversified corporate groups. Size is already a problem even when products are homogeneous. Further complexity is added when organizations possess a diversity of products or operations which are not related in terms of either marketing or manufacturing. In these organizations, the need for planning as a coordinating function becomes readily apparent.

It was judged that the Financial Mail 'Top 100 Companies' list would comprise companies of this nature.

\section{Data collection}

Having decided that the principal data base required was related to the extent to which South African companies experienced the need for and undertook manpower planning, and that this was inextricably linked to the corporate planning process within these companies, the question arose as to how best this data could be obtained. After considering several alternatives it was decided to visit the companies individually and obtain the data from those persons directly involved in the function through the medium of a structured interview. It was argued that this approach would provide the most accurate data and avoid the problems of bias, misinterpretation and non-response inherent in the other approaches considered.

The questions which comprised the interview guide or schedule were formulated after a theoretical model on corporate and manpower planning was developed from the literature review. In addition, the checklist for use in developing a questionnaire suggested by Boyd, Westfall \& Stash (1977) was used as a guide in determining which questions should be included. The approach was pilottested on directors of two companies which did not fall into the sample group and the necessary amendments made.

A letter explaining the purpose of the research was written to the CEO's of the 25 companies in the sample.
They were later contacted by telephone and the necessary appointments arranged. All 25 companies randomly selected in the initial sample agreed to participate in the research project. Interviews with representatives of the 25 companies were conducted over a two-month period on the premises of each company and in a venue determined by the interviewee.

\section{Analysing the data}

This study is of an exploratory nature aimed at obtaining qualitative answers to the questions posed. As there were no ready-made theoretical categories into which the array of raw data could be systematically classified for further analysis, it became necessary to formulate these categories from scratch.

The classification system developed is based on the model suggested by Lazarfeld \& Barton (1955). Their model emphasizes four processes, namely,

a. Articulation: Classification of a great number of individual items into a smaller number of groups raises major problems. A solution to these problems is to use 'articulate' classifications: classifications with several steps, starting with a few broad categories and breaking them down into many more detailed categories. Thus, when a few broad categories are sufficient only the simple first step need be used; when a more detailed study is required, the finer distinctions can be preserved in the later steps of the classification system. Results presented in this way are easier to read, make more sense and can be handled statistically in ways which would otherwise be impossible.

b. Logical correctness: A classification meets the requirement of logical correctness if it provides exhaustive and mutually exclusive categories at each step of the classification. Mutual exclusiveness means that there should be one and only one place to put an item within a given classification system.

c. Adaptation to the structure of the situation: The most important aspect of developing a classification system is the setting up of those special categories which will be best suited to the material and problem being studied. In many cases the researcher simply uses the customary terms of everyday life. However in exploratory research, the investigator has to develop his own categories.

One starts with a collection of responses. It is usually not possible to arrive at a satisfactory classification system simply by grouping items which seem similar in content. Rather it is necessary to build up a concrete picture or model of the whole situation to which the study refers. This involves an interactive process. First, it is necessary to visualize the concrete processes and activities implied by the responses through introspection and imaginative qualitative analysis of the data to get a preliminary scheme. One then tries to apply this scheme systematically to the data, returning to the structural scheme for refinement, reapplying the revised scheme to the data, and so on. One may thereby end up with a classification rather different from that with which one started.

d. Adaptation to the respondent's frame of reference: The 
classification should present as clearly as possible the respondent's own definition of the situation - his focus of attention, his categories of thought.

\section{Analysis and interpretation of the findings}

The following conclusions are drawn from the many findings and insights gained.

\section{The corporate planning process}

Of the 25 companies surveyed, 23 ( $92 \%$ of the sample) had a separate formal planning function. The respondents of the remaining two companies indicated in the one instance that planning was not perceived as a necessity and that in the other, the company was in the process of hiring the services of a corporate planner and formalizing the planning function.

\section{Reasons for corporate planning}

Because planning presents new possibilities for dealing with change, it is seen differently by different people and may be required to satisfy a wide variety of needs.

Although each situation differed, a number of common factors emerged in the companies most convinced of the need for corporate planning. Many have experienced rapid internal and external change; existing methods of dealing with change have been inadequate and, in many instances, the inability to deal with change effectively has threatened their very existence and survival.

Other companies were operating in an increasingly competitive environment. The trend has been towards larger operating units as companies integrate both vertically and horizontally to protect markets and raw material supplies. Yet growth brings its own problems as the organization gets bigger its various segments can no longer operate in isolation, nor can new investments be made on an ad hoc basis. Growth through diversification can result in rapid changes in the balance of activities which give rise to a need for greater coordination and a unified sense of direction.

At the same time, relationships between people and authority are changing. Autocracy is in decline and there

\section{Table 3 Planning horizon}

\begin{tabular}{ccc}
\hline Time span (years) & No. of companies & \% of Total \\
\hline 1 & 4 & 16 \\
2 & 1 & 4 \\
3 & 10 & 40 \\
5 & 13 & 52 \\
10 & 3 & 12 \\
15 & - & - \\
$>15$ & - & - \\
\hline
\end{tabular}

The percentage totals more than 100 as some companies have more than one planning cycle
Table 4 Inputs from key functional areas

\begin{tabular}{lcc}
\hline Key functional areas & No of companies & \% of Total Sample \\
\hline Finance & 23 & 92 \\
Marketing & 23 & 92 \\
Production & 18 & 72 \\
Manpower & 18 & 72 \\
Material & 13 & 52 \\
Mach. \& Equip. & 8 & 32 \\
Other & 13 & 52 \\
\hline
\end{tabular}

- Two companies do no formal planning

- Table incorporates multiple responses

is a growing trend towards a more participative style of management. Furthermore, a better informed and educated generation of managers is emerging who are exerting increasing pressure for a more professional management approach.

\section{Planning horizon}

Table 3 indicates the planning time span of the companies involved. Companies plan ahead for varying time periods. While the majority $(52 \%)$ plan ahead for five years, the three-year planning horizon is also very popular $(40 \%)$. The volatility of the economic climate has considerable influence on the selection of the planning period. Companies that are sensitive to changes in the macro environment plan for shorter periods. Companies also resort to a system of multi-tiered planning, a one-year operational plan, a three-year intermediate and a five-year long range plan. It was found that the more comprehensive the planning effort, the further ahead the companies planned.

\section{Functional input into the corporate plan}

Table 4 indicates the degree to which input from the key functional areas is included in corporate plans.

Finance and marketing plans feature predominantly in the corporate plans, with $92 \%$ of the companies surveyed (all companies who have a formal planning process) including these inputs in their plans.

Production and manpower issues feature second most prominent in terms of functional input, with 18 companies or $72 \%$ of the sample including production and manpower issues in their corporate plans.

It is interesting to note that of the five companies that do not include manpower plans in their corporate plan, two are Industrial Holding companies, one is a Building and Construction company, and one is an Engineering company. These companies are directly or indirectly involved in the building industry. The building industry is extremely sensitive to changes in the macro-economic environment, which is cyclical with deep troughs and high peaks.

The impact of the volatility of the environment on the human resource policies of these companies is discussed in more detail later. 


\section{Management involvement in the planning process}

Without exception, all respondents stressed that corporate planning could not get off the ground without the active support of the $\mathrm{CEO}$. In practice however, a different picture emerges. Actual management involvement in the planning process is reflected in Table 5.

The corporate planning process in $80 \%$ of the companies is a bottom-up process. If planning is to make any progress at all, then not only does the company need the total commitment of the $\mathrm{CEO}$ but also line management must be motivated towards it. Ringbakk (1971) confirms this view by explaining that planning fails because management at the top, although recognizing in principle the importance and desirability of formal planning, do not stimulate the necessary action and involvement.

\section{Control of corporate plans}

Table 6 reflects the outcome of the questions relating to the review and revision of corporate plans.

Seventy-six per cent of the companies (19 companies) involved in the study adopted the rolling plan concept. This means that corporate plans are revised annually, adding to the plan another year at the end of each year. Respondents believed that the rolling plan allowed their companies to retain flexibility in a rapidly changing environment.

Table 5 Management involvement in the planning process

\begin{tabular}{lcc}
\hline Management level & No of companies & $\%$ of Total sample \\
\hline Chief executive officer & 21 & 84 \\
Director of each department & 19 & 76 \\
Manager of each department & 9 & 36 \\
Line manager & 20 & 80 \\
Foreman & - & - \\
Workers/employees & - & - \\
Others & 10 & 40 \\
\hline
\end{tabular}

Table incorporates multiple responses

Table 6 Review and revision of corporate plans

\begin{tabular}{lcc}
\hline Frequency of review and revision & $\begin{array}{c}\text { No of } \\
\text { companies }\end{array}$ & $\begin{array}{c}\text { \% of Total } \\
\text { sample }\end{array}$ \\
\hline Monthly & 4 & 16 \\
Quarterly & 1 & 4 \\
Half yearly & 2 & 8 \\
Annually & 20 & 80 \\
Other & 1 & 4 \\
Rolling plan & 19 & 76 \\
\hline
\end{tabular}

Table incorporates multiple responses
The integration of corporate planning and manpower planning

The relationship between corporate planning and manpower planning

Seventy-two per cent of the companies surveyed (18 companies) acknowledged that there is a close relationship between corporate planning and manpower planning.

The function of the manpower planner is seen to be one of providing healthy viable resources from which the corporate planner can draw in formulating and implementing his strategic plan. As a respondent from a company in the Food Industry commented, 'Corporate planning is not all products, markets and finance. People are becoming increasingly important, and in the last resort, one of the key resources available to management is simply the number and quality of the people on whom we can draw.' The view was also expressed that the organization comprises a number of dimensions and systems. Every organizational dimension must be consistent, not only with the strategy but also with every other organizational dimension and system. This is in line with Schendel's thinking (1979: 265) when he states that, "All the dimensions, such as structure, reward systems and allocation processes must constitute an internally consistent organisational form'.

One respondent from the Manufacturing sector stated that his organization's employees are experiencing technological changes on several interrelated fronts that will need immediate attention. First is the increasing sophistication in information technology, which combined with the declining productivity of labour, has fostered the emergence of robotics. This clearly means the displacement of labour. When workers are retrenched or retrained it means a phase of job uncertainty, potential unemployment and the attendant problems of increased unionism, social unrest and political militancy. If companies are to revamp their production processes, then they must understand the human resource implications of these trends. He summed up by saying, 'effective organizational performance in the $1980 \mathrm{~s}$ and $1990 \mathrm{~s}$ will require effective human resource management'.

One financial director summarized his company's philosophy with the statement that meshing manpower planning with corporate planning makes eminently good sense. According to him, even the best strategic business plan has little hope of success if the right people are not in place at the right time to implement it.

The five companies that do not include manpower plans in their corporate plans are all directly or indirectly involved in the building industry. Although these companies have long-range corporate plans, any planning beyond two years is mainly qualitative. The peaks and troughs of the building industry cannot be predicted. A respondent of one company admitted that his company's operations in terms of manpower planning were highly inefficient. He explained that during the depressed periods the company could not afford to retain skilled professional staff, and these were thus 
retrenched. Because the movements in the industry were unpredictable, the company was totally unprepared for an upswing. During these periods they experience a shortage of skilled and professional staff. Productivity decreases because short-staffed projects were badly managed.

The other companies have had similar experiences. These companies attempt to solve their manpower problem by 'importing' the required staff on contract from overseas countries.

\section{The manpower planning process}

Of the companies surveyed only three have comprehensive, dedicated manpower information systems. The other companies used payroll, personnel administration or other such secondary sources for manpower information.

A review of the literature (Pettman \& Tavernier, 1976; Walker, 1980 and Hofmeyr, 1980) identified eight primary activities in the manpower planning process. Table 7 reflects the response of the companies surveyed to the inclusion of these activities in their manpower planning process.

Table 7 Activities included in the manpower planning process

\begin{tabular}{|c|c|c|}
\hline Stages in the process & $\begin{array}{c}\text { No of } \\
\text { companies }\end{array}$ & $\begin{array}{c}\% \text { of Total } \\
\text { sample }\end{array}$ \\
\hline \multicolumn{3}{|l|}{ 1. Define overall corporate } \\
\hline objectives for the planned period & 13 & 52 \\
\hline \multicolumn{3}{|l|}{ 2. Convert corporate objectives } \\
\hline into manpower objectives & 13 & 52 \\
\hline \multicolumn{3}{|l|}{ 3. Design a manpower information } \\
\hline system & 10 & 40 \\
\hline 4. Undertake a manpower inventory & 12 & \\
\hline 5. Forecast future manpower needs & 19 & 76 \\
\hline 6. Project future manpower supply & 19 & 76 \\
\hline \multicolumn{3}{|l|}{ 7. Compare forecast needs with } \\
\hline projected supply & 19 & 76 \\
\hline \multicolumn{3}{|l|}{ 8. Planned policies and programmes } \\
\hline to meet human resource needs & 15 & 60 \\
\hline
\end{tabular}

Table incorporates multiple responses

Only seven of the 17 companies that make some attempt at planning their manpower needs include all activities. This would create the impression that South African companies make a half-hearted attempt at planning their human resource needs. However, seven of the remaining 10 companies include the core activities of the planning process. These companies forecast future manpower needs, project future manpower supply, compare forecasted needs with projected supply, and plan policies and programmes to meet resource needs.

\section{Implications of manpower on corporate decision making}

Respondents were asked to relate instances in their companies where manpower implications had affected the decisions made at corporate level. Ten companies ( $40 \%$ of the sample) were able to relate such instances. These decisions included the postponement of expansion programmes; non-acquisition of financially viable companies; introduction of training programmes for staff and the introduction of mechanization and automation. Those companies that disregarded the human resource implications when setting corporate objectives $(52 \%$ of the sample) resolved their manpower problems by recruiting from the labour market at premium salaries or wages, by poaching staff, by sub-contracting, or by recruiting from abroad.

\section{The role of the chief manpower planner}

It was found that the role of the manpower planner was directly related to the length of time manpower planning had been in existence in the company. If manpower planning was a new concept in the company, the manpower planner assumed the role of 'provider of ideas, opinions and technical information', in other words, a specialist role. In companies where manpower was not a totally new concept the planner's role was such as one of 'prescribing action' - a consultant role. In those companies where manpower planning was an established function, the role was seen as one of 'collaborator', where, together with operating management needs were defined and alternative solutions to emerging problems sought. They were seen as coordinators, responsible for initiating, collecting and collating divisional plans and advising on the scope, techniques and time-tabling plus integration of the long and short-term plans and monitoring all progress towards meeting these plans.

The nature of the relationship between corporate planning and manpower planning

\section{The impact of manpower planning}

The companies recognized three fundamental ways in which manpower planning could influence the organizations' capacity to achieve corporate goals. The impact of manpower planning on cost was considered important by $70 \%$ of the sample. Manpower, like materials, buildings, plant and machinery is considered an investment, subject to the same cost, allocation and return control considerations. The focus is on efficiency and effectiveness in terms of minimum cost and effective utilization to obtain an acceptable return on investment.

The impact of manpower on the organization's capacity to operate effectively was recognized by $60 \%$ of the sample. The fundamental objective of manpower planning was to provide the organization with personnel to perform the activities that would achieve organizational goals.

Manpower planning also influences the companies' capacity to undertake new ventures or to change operations. This was recognized by $48 \%$ of the sample. Any plans for acquisitions and mergers, the expansion of plant capacity, a change in product mix, etc. must include provision for the human resource implications of such change. 
Table 8 Importance of manpower planning

\begin{tabular}{lcc}
\hline & No of companies & $\%$ of Total sample \\
\hline $\begin{array}{l}\text { More important than other } \\
\text { functions }\end{array}$ & - & - \\
As important as other & 11 & 44 \\
$\quad$ functions & & \\
Less important than other & 7 & 28 \\
$\quad$ functions & 4 & 16 \\
Not important at all & 3 & 12 \\
Others & 25 & 100 \\
Total & & \\
\hline
\end{tabular}

Importance of manpower planning in the total planning process

The respondents answers to this question are reflected in Table 8.

None of the companies considered the contribution made by the manpower planner as more important than that made by other functional planners. Traditionally, the personnel departments have accepted backwater positions in organizations. The staff's responsibilities had been confined to insignificant activities, unrelated to the attainment of company objectives.

The findings, however, indicate that the status of the personnel department is improving. Forty-four per cent of the sample now accord the same status to manpower planning as they do to the planning of the other functions. Companies have realized that it is essential that the manpower planner is fully integrated into the company. He must be a member of the company's top team, and must report directly to and have the commitment and support of the chief executive officer. The manpower planner can make an impact on organizational effectiveness only if he is involved in the company's long-range planning. If he is not, he cannot make any contribution other than on a day-to-day, firefighting basis.

Despite the improved status of the manpower planner there are still companies, in fact $32 \%$ of the sample, that consider manpower planning to be of no value.

\section{Manpower planner's knowledge of the company's business}

In response to the question, 'How well does the manpower planner have to know the business?', 18 companies ( $72 \%$ of the sample) that included manpower planning in their corporate plans said it was very important for the manpower planner to have a thorough knowledge of the core technology of the business. In 15 of the companies, the person responsible for manpower planning had been appointed to the position from within the company. The respondents indicated that the advantage of an internal appointment to the position is that the person has a thorough understanding of the organization and the industry within which it operates.
Table 9 Communication flow

\begin{tabular}{lcc}
\hline Process & No of companies & $\%$ of Total sample \\
\hline Top-down & 3 & 12 \\
Bottom-up & 10 & 40 \\
Interactive & 6 & 24 \\
Other & 6 & 24 \\
Total & 25 & 100 \\
\hline
\end{tabular}

\section{Communication flow in the planning process}

The manpower planning process in the South African companies may be classified into three types: 'Top down', 'Bottom up' and 'Interactive'. These relate to where the basic idea is presented, where the plan is reviewed and how the final plan is approached.

Table 9 reflects the responses from the companies to the question of communication flow in the planning process.

The bottom-up process of manpower planning is more frequently used $(40 \%)$ than are the other two. This is not unusual considering the structure of the companies participating in the study. Eighteen of the 25 companies are decentralized. Decentralization in these companies has occurred by product, by plant, by subsidiary and by geographical location of the operating unit.

The steps that were followed by these companies in the planning process are similar in that the broad corporate goals and objectives are set by corporate executive and usually stated in broad financial terms (e.g. expected increase in tunrover, ROI, ROA, etc). These are then communicated to the chief executive officers of the operating units who are then expected to develop the detailed plans to meet the corporate objectives.

The three companies (12\%) that use the 'top-down' approach to planning are undiversified in their products and business activities. All three have a strong central planning function with little autonomy delegated to the operating departments or units.

Six ( $24 \%$ of the sample) use the interactive approach to manpower planning. The approach was described by the spokesperson for an Industrial Holding company as follows: '... the objectives are formulated by interaction between top management, the planning department and operating units. The planning department collects environmental information on manpower and submits strategy issues to the top. The top management decides the goals and broad direction. Then by vertical interaction, final strategies are formulated'.

This approach was confirmed by a respondent from another company, who described the process that had developed as follows: 'Initiating an effective corporatedivisional goal-setting climate was a difficult task. The CEO decided that for the first two years the best approach was to allow the managers to set goals for their own divisions. This encouraged broad strategic thinking at the divisional level. Subsequently, after the corporate and divisional managers had gained some experience in 
formulating a mutually agreeable set of divisional goals, the divisional manager's annual proposal for divisional goals was less constrained than in the early years. Now divisional goal-setting has become a negotiation process between top management and divisional managers.'

Two companies ( $8 \%$ of the sample) do not do any planning. The remaining five companies $(20 \%$ of the sample) do not link their manpower plans to their corporate plans.

The development of the relationship between corporate planning and manpower planning

\section{Introduction of manpower planning}

The starting point of manpower planning is an awareness of a need and the presumption of the planning concept as the most effective way of satisfying the need. However, in many cases, it is apparent that need awareness 'won't make planning happen' and therefore it becomes necessary to distinguish between the need for planning and the event which provides the stimulus for its introduction. As Ansoff (1965: 123) observes: 'Unlike operating and administrative decisions, strategic decisions are not self-regenerative. Attention to strategy is either assured on a continual basis through special organizational arrangements or it remains dormant until triggered off by some major event inside or outside the firm'.

Although this statement was made some 22 years ago it still holds true as this study confirmed that the need for manpower planning and the stimuli which forced its introduction were not always the same. In some companies the need had been apparent for some time but some event resulted in action that translated it into meaningful practice. In other companies, the need and event was perceived as one and the same.

Table 10 indicates the date manpower planning was introduced into the companies surveyed.

The two companies in Table 10 that introduced manpower planning during the 1960 s admitted that manpower planning practices at that time were focused mainly on balancing labour supply with demand. The manpower planners focused their attention on needs for manpower in the future, forecasted their internal labour supply for meeting these needs, and identified the gaps between what will be needed and what will be available. These companies considered manpower planning a necessary process for allocation of scarce resources. Manpower planners developed plans for recruiting,

\section{Table 10 Date of introduction of manpower planning}

\begin{tabular}{lcc}
\hline Date of introduction & No of companies & $\%$ of Total sample \\
\hline Earlier than 1960 & 1 & 4 \\
In the 1960s & 2 & 8 \\
In the 1970s & 11 & 44 \\
In the 1980s & 5 & 20 \\
Other & 6 & 24 \\
Total & 25 & 100 \\
\hline
\end{tabular}

selecting and placing new employees, providing for training and development and anticipating necessary promotions and transfers.

The companies that introduced manpower planning in the 1970s adopted the techniques that had been introduced by leading companies during the previous decades, but in addition, they experimented with new tools such as career planning, activity analysis and remodelling of work. During this decade manpower planning - also broadly termed 'human resource' planning - became widely established as a staff activity. The term 'human resource planning' implied a scope broader than merely supply-demand balancing or quantitative forecasting. The companies shifted their attention from these parts of the process, although recognizing their importance, to the more comprehensive view of the process encompassing both needs forcasting and programme planning.

Finally, companies that introduced manpower planning in the early $1980 \mathrm{~s}$ responded to the employee's desire for participation in making decisions that affect their work and career. Another reason given by respondents was management's desire for improved control over labour costs and profitability.

The company that had done manpower planning before 1960 had actually responded to the talent shortage experienced during World War II. During the post war years the planner's attention was focused mainly on employee productivity.

Four of the six companies in the 'other' category do not do any manpower planning. The remaining two companies do no planning at this stage.

\section{The stimuli for planning}

Most companies that introduced planning during the late 1970s maintained the depressed economy was the main reason for manpower planning assuming a more powerful stance. One respondent described the introduction as follows: '... the going had been tough, profits had been hard to come by and the cost of labour had kept moving up. In addition, the company had expanded rapidly during the 1960's and had found that the expansion programme had left a tangle of incompatible compensation plans and scores of highly paid executives who seemed to be in the wrong jobs. The company wanted a more efficient system of appointing and promoting managers. Manpower planning was the only answer to the company's problem at that crucial time.'

Ironically, one company that introduced manpower planning in the early 1980s mentioned the booming economy as the main stimulus for the company's decision. Increased profits enabled the company to expand its operations. This also meant an increase in the need for skilled staff. However, South Africa was experiencing a shortage of skilled manpower. Thus the company was not able to recruit suitably qualified staff. To utilize its available staff effectively, it was important for this company to plan its manpower.

The respondent for a company in the Finance sector 
said that the technological developments in that industry were influential in the introduction of manpower planning. The introduction of electronic office equipment increased the speed of data processing to such an extent that a large number of clerks became redundant. However, office automation created jobs for which there were no skilled people. The company then began to train its redundant clerks for new jobs. This process of matching clerks to newly created jobs gradually evolved into a manpower planning process.

A respondent for a large manufacturing company expressed his view as follows: '... the last economic depression made us realise that the process of redundancy and retrenchment must be managed just as any other function within the company. The company has an elaborate and detailed selection policy, but has nothing on de-selecting people. When the company has had to retrench staff, it blundered and handled it badly, adversely affecting staff morale and public image. The company then realised the crucial significance of careful manpower planning on a continuous basis. The personnel manager admitted that during the economic boom the company could afford to, and did carry superfluous staff. This, however, became a burden during periods when the economy was depressed. We soon realised that the solution to the retrenchment problem was a continuous review of the company's staff requirements and the periodic termination of inefficient employees.'

An executive of a large organization in the retail industry gave the turnover of management staff as the stimulus which triggered off manpower planning in his company. The high turnover not only meant employee wastage but also a cost in financial terms. The cost included the cost of lost sales and services and costs associated with exit interviews and administration of the termination of service. Then there were costs for coverage of unfilled vacancies. Finally there were costs in the form of advertising agency fees, interviewing, testing and reference checking the placement, the induction period, low productivity and further training. In addition to these direct costs, the company incurred indirect costs of disruption, lowering of morale among other staff and the adverse effect on the company's image. After much searching and questioning the CEO found that managers were frustrated by the company's lack of interest in them and their career development. They were leaving the company for jobs that offered promotions and responsibility, as well as wider experience. To retain its highly skilled and highly motivated management staff the company introduced manpower planning.

In three companies, manpower planning was introduced because it was recommended by consultants. One respondent explained that manpower planning in his company was introduced because of changes on the board. These changes had occurred because of unsatisfactory performance. The company was experiencing serious problems which were in such an advanced stage that the help of outside consultants had to be sought. The consultants recommended the introduction of corporate planning. The process prescribed by these consultants included manpower planning.

\section{Benefits derived from manpower planning}

Companies participating in the study were asked what benefits, if any, had been derived from manpower planning.

While any assessment of the benefits as articulated by the respondents must be perceived as being largely subjective, it is interesting to note that virtually all respondents were positive about the benefits derived. It is not practical to list all the benefits claimed, but following is a summary of the responses with detailed explanations added where deemed appropriate:

-Improved understanding of the human resource implication on business strategy. One respondent illustrated the emergence of this realization as follows: '... In the early 1970's our company had embarked on a massive expansion programme. Existing plants were expanded and new production facilities added without planning for the grooming of necessary managers. As a result start-ups were sometimes delayed and problems were encountered due to inadequate experience and training of key personnel. After several such experiences the company introduced manpower planning. The achievement of business objectives became that much easier. A similar expansion programme as in the 1970's was planned in 1981. However, the company anticipated its requirements for new plant managers and senior technical personnel. It systematically rotated prospective candidates among plants and pertinent headquarters and regional staff positions to satisfy the projected needs'.

-Improved and more effective career management. The limited supply of competent talent and changing organizational requirements forced many companies to focus on career development. This has resulted in greater retention of staff and the improved utilization of talent. Recruiting and selection practices now focus on job relevant criteria such as specific skills, knowledge and experience required to successfully perform the job. There is an increasing concern with the quality and not only the quantity of talent employed.

- Management development and managerial succession planning. Competition, rapid organization and technological changes, financial pressures and many other demands on organizations has emphasized the need for more broadly experienced and rigorously tested and seasoned managers. Effective manpower planning has provided managers with such experience through planned rotational job assignments.

- Redundancy and retrenchment planning. Companies are able to plan in advance for staffing and related career development and organizational changes. Unproductive people and systems can be identified and appropriate action taken. Companies are able to reduce their workforce during economic down-turns in a planned way without adverse effect on staff 
morale. One company stated that planned retrenchment had served as a positive motivator for remaining individuals as they were assessed to be better then the average.

-The ability to recruit experienced talent well in advance of needs. By processing their manpower effectively, companies were able to analyse in detail the nature of the work actually to be performed and thus develop a specific set of job-relevant criteria used for seeking and screening prospective job applicants.

-Aiding in the achievement of corporate objectives. Those companies that planned the use and disbursement of their resources, including their human resources, extensively claimed that their performance has improved significantly. Setbacks have been experienced, but these are not attributable to manpower deficiencies or problems.

\section{Recommendations and areas for further research}

Bearing in mind that this was an exploratory study which focused primarily on the relationship between corporate planning and manpower planning and was designed to provide a general overview of the present situation in South Africa, the following recommendations are offered:

1. Companies should shift their focus from quantitative thinking to more fundamental qualitative thinking. Much planning in South African companies can be described as extended budgeting. Underlying causal factors such as changing demographic, technological and competitive trends and the dire need for competent, effective and innovative people which often determines the long-term viability of businesses are generally not adequately covered.

2. Companies re-examine the involvement of all levels of management in the planning process. Although senior management has recognized the importance and desirability of planning, the necessary action and involvement to complete the process and ensure its success has not been forthcoming.

3. Companies improve their manpower planning process. Many companies confine their manpower planning to balancing the supply and demand of business resources and quantitative forecasting. Although these elements of the process are important, the focus of attention must shift to a more comprehensive view of the process, encompassing not only need forecasting but programmes to develop and more effectively utilize the human resources to the best long-term advantage of the organization.

4. Companies not planning their manpower reconsider their strategy. Companies can no longer rely on traditional sources of high-level manpower for myriad economic and socio-political reasons. The development of alternative sources will require careful and detailed planning and execution of these plans.

5. Individuals responsible for manpower planning improve their skills in this area. The rapid technological, economic, social and political changes facing us reflect an age characterized by complexity and interdependence requiring sophisticated, 'state of the art' systems and procedures to gather, coordinate, process and report on this information. Job analysis and classification systems appropriate to the industry, performance and potential appraisal systems, career and succession planning and management systems that work and are acceptable to all parties concerned, will be increasingly called for in the future. However, the measure of success of the manpower planner will not be the fact of installing systems or conducting programmes, but rather their impact on meeting identifiable organizational needs.

6. Companies pay greater attention to the impact of manpower planning on the cost economics of the company. Companies are inclined to focus their attention on financial management, cash flow analysis, revising inventory valuations and computer modelling for marshalling all the corporate resources into avenues to optimize profits. In assessing all of these areas, however, one of the most important and costly areas is often totally overlooked, namely, the planning, controlling, effective utilization and motivation of corporate human assets. For the vast majority of companies, salary costs are the heaviest contributor to expenses. To this are added the cost of taxes and levies, medical aid, pensions, and other benefits.

7. Human Resource executives take a long hard look at the status of personnel management and manpower planning in their companies. The organization comprises a number of varying dimensions and systems. Every organizational dimension and system must be consistent, not only with the strategy, but also with every other organizational dimension and system. Each dimension of management has an integrity of its own and if the organization is to function effectively, the component dimensions of the management system must be compatible. The integrity of the personnel function is at stake if it is not included in the formulation of overall corporate goals and objectives and the strategy to be used in achieving such goals and objectives.

8. Those companies that use the centralized 'top-down' approach to manpower planning examine the effectiveness of their plans. One of the foundations of sound corporate planning is a strong system of operational planning. Thus, once the broad parameters are set, the chief manpower planner should allow the managers of operating units to demonstrate how they intend to go about providing their share of the action which will attain the companies' manpower objective.

This study has also highlighted a number of areas for meaningful further investigation. The role and contribution of corporate planning in a rapidly changing environment; the efficacy of current manpower planning systems in meeting organizational needs; developing a comprehensive model for manpower planning; new 
techniques for acquiring and interpreting meaningful human resource information, are all areas that require further investigation.

\section{References}

Abratt, R. 1983. Interrelationship between Human Resource Management and Corporate Strategy. S. Afr. J. Bus. Mgmt. vol.14, 53-59.

Andrews, K.R. 1971. The Concept of Corporate Strategy. Homewood: Dow A Jones - Irvin Inc.

Ansoff, I.H. 1965. Corporate Strategy. New York: McGraw-Hill.

Anthony, R.N. 1965. Planning and Control Systems - A Framework for Analysis. Boston: Harvard University.

Argenti, J. 1968. Corporate Planning : A Practical Guide. London: George Allen and Unwin Limited.

Boyd, H.W. Jr., Westfall, R. \& Stash, S F. 1981. Marketing Research : Test and Cases. 5th Edition. Homewood: Richard D Irwin Inc.

Drucker, P.F. 1974. Management: Tasks, Responsibilities, Practices. Revised Edition. New York: Harper and Row.

Fayol, H. 1969. General and Industrial Management. London: Pittman Paperbacks.

Financial Mail. 1987. Emigration. Finan. Mail, January 9, p.31.

Financial Mail. 1984. Top Companies, Financial Mail Special Survey. Finan. Mail, May.
Hofmeyr, K.B. 1980. Manpower Planning - How to do it. People and Profits, June.

Hussey, D.E. \& Langham, M.J. 1979. Corporate Planning : The Human Factor. Oxford: Pergarmon Press.

Lazarfeld, P.F. \& Barton, A.H. 1955. Language of Social Research. New York: The Free Press.

Management. 1974. PE Consulting Group Management. What Long Range Planning has Done (and not done) for the 'Top 100' Companies. Manage. May.

Pettman, B.O. \& Tavernier, G. 1976. Manpower Planning Workbook. Great Britain: Gower Press Limited.

Ringbakk, K.A. 1971. Why Planning Fails. Europ. Bus., Spring.

Ringbakk, K.A. 1969. Organised Planning in Major US Companies. Long Range Planning, vol.2, December.

Rossotti, C.O. 1970. Two Concepts of Long Range Planning : An Analysis of Current Practice. Boston: The Boston Consulting Group.

Schendel, D.E. 1979. Strategic Management. Boston: Little, Brown and Co.

Scott, B.W. 1965. Long Range Planning In American Industry. New York: American Management Association.

Steiner, G.A. 1969. Top Management Planning. London: MacMillan and Company.

Walker, J.W. 1980. Human resource planning. New York: MacGraw-Hill. 